\title{
Pancreatic $\beta$-cell prosurvival effects of the incretin hormones involve post-translational modification of Kv2.1 delayed rectifier channels
}

\author{
S-J Kim ${ }^{1,3}$, SB Widenmaier ${ }^{1,3}$, wS Choi ${ }^{1,4}$, C Nian $^{1}, \mathrm{Z} \mathrm{AO}^{2}$, G Warnock ${ }^{2}$ and CHS McIntosh ${ }^{\star, 1}$
}

Glucose-dependent insulinotropic polypeptide (GIP) and glucagon-like peptide-1 (GLP-1) are the major incretin hormones that exert insulinotropic and anti-apoptotic actions on pancreatic $\beta$-cells. Insulinotropic actions of the incretins involve modulation of voltage-gated potassium (Kv) channels. In multiple cell types, $\mathrm{Kv}$ channel activity has been implicated in cell volume changes accompanying initiation of the apoptotic program. Focusing on Kv2.1, we examined whether regulation of $\mathrm{Kv}$ channels in $\beta$-cells contributes to the prosurvival effects of incretins. Overexpression of Kv2.1 in INS-1 $\beta$-cells potentiated apoptosis in response to mitochondrial and ER stress and, conversely, co-stimulation with GIP/GLP-1 uncoupled this potentiation, suppressing apoptosis. In parallel, incretins promoted phosphorylation and acetylation of Kv2.1 via pathways involving protein kinase A (PKA)/mitogen- and stress-activated kinase-1 (MSK-1) and histone acetyltransferase (HAT)/histone deacetylase (HDAC). Further studies demonstrated that acetylation of Kv2.1 was mediated by incretin actions on nuclear/cytoplasmic shuttling of CREB binding protein (CBP) and its interaction with Kv2.1. Regulation of $\beta$-cell survival by GIP and GLP-1 therefore involves posttranslational modifications (PTMs) of Kv channels by PKA/MSK-1 and HAT/HDAC. This appears to be the first demonstration of modulation of delayed rectifier Kv channels contributing to the $\beta$-cell prosurvival effects of incretins and of 7-transmembrane $G$ protein-coupled receptor (GPCR)-stimulated export of a nuclear lysine acetyltransferase that regulates cell surface ion channel function.

Cell Death and Differentiation (2012) 19, 333-344; doi:10.1038/cdd.2011.102; published online 5 August 2011

Type 1 and Type 2 diabetes are associated with absolute or relative deficits of functional $\beta$-cells, and there is growing evidence that apoptosis is the main mediator of $\beta$-cell death. In view of the worldwide increase in diabetes incidence, it is important to understand the molecular mechanisms involved in $\beta$-cell apoptosis and to identify the agents that can reduce or abrogate this process.

The gastrointestinal tract secretes over 20 peptide hormones that regulate multiple physiological processes. Among these, glucose-dependent insulinotropic polypeptide (GIP) and glucagon-like peptide-1 (GLP-1) are the major incretin hormones that potentiate glucose-stimulated insulin secretion (GSIS) during a meal, ${ }^{1,2}$ and exert beneficial effects on $\beta$-cell proliferation and survival. ${ }^{2-6}$ GSIS involves closure of ATPsensitive $\mathrm{K}^{+}\left(\mathrm{K}_{\text {ATP }}\right)$ channels resulting in membrane depolarization, activation of voltage-dependent $\mathrm{Ca}^{2+}$ channels and increased intracellular $\mathrm{Ca}^{2+}$, followed by membrane repolarization by voltage-gated $\mathrm{K}^{+}(\mathrm{Kv})$ and $\mathrm{Ca}^{2+}$-sensitive $\mathrm{K}^{+}$ $\left(\mathrm{K}_{\mathrm{Ca}}\right)$ channels. Incretins stimulate insulin secretion through modulation of $\mathrm{K}_{\text {ATP }}$ channel activity, increasing $\mathrm{Ca}^{2+}$ influx through L-type $\mathrm{Ca}^{2+}$ channels and non-selective ion channels, and releasing $\mathrm{Ca}^{2+}$ from intracellular stores, as well as potentiation of $\mathrm{Ca}^{2+}$-dependent exocytosis. ${ }^{2,3,7}$ These effects are mediated through activation of $\beta$-cell $\mathrm{G}$ proteincoupled receptors (GPCRs). ${ }^{2,3}$ Both GIP and GLP-1 stimulate adenylyl cyclase, leading to increased intracellular cyclic AMP (cAMP), and activate protein kinase $A(P K A)$ and exchange protein directly activated by CAMP 2 (EPAC2). ${ }^{2,3}$

Incretins activate both transcription-dependent and -independent anti-apoptotic pathways in $\beta$-cells ${ }^{2-6}$ and significant progress has been made in elucidating the underlying mechanisms. Staurosporine (STS)-induced mitochondrial translocation of Bad and BimEL, activation of mitochondrial Bax, release of cytochrome $c$ and caspase-3 activation were all reduced by GIP treatment of $\beta$-cells. ${ }^{6}$ Incretins additionally reduce the levels of ER stress-related factors. ${ }^{1,3}$ The cAMP/ PKA pathway has a central role in $\beta$-cell prosurvival effects of GIP and GLP-1, ${ }^{1,3,5}$ including stimulation of CREB-mediated expression of genes such as $b c /-2 .^{5}$ Anti-apoptotic effects of PKB are also activated by the incretins, with suppression of

\footnotetext{
${ }^{1}$ Departments of Cellular \& Physiological Sciences and the Diabetes Research Group, Life Sciences Institute, University of British Columbia, 2350 Health Sciences Mall, Vancouver, BC, Canada and ${ }^{2}$ Department of Surgery, University of British Columbia, 2350 Health Sciences Mall, Vancouver, BC, Canada

${ }^{*}$ Corresponding author: CHS McIntosh, Department of Cellular \& Physiological Sciences, The Diabetes Research Group, Life Sciences Institute, University of British Columbia, 2350 Health Sciences Mall, Vancouver, BC, Canada V6T 1Z3. Tel: + 1604822 3088; Fax: +1 604822 6048; E-mail: mcintoch@mail.ubc.ca

${ }^{3}$ These authors contributed equally to this work.

${ }^{4}$ Current address: Institut Pasteur Korea, Seoul, South Korea

Keywords: incretins; diabetes; GIP; GLP-1; $\beta$-cell apoptosis; Kv channel

Abbreviations: ANOVA, analysis of variance; AVD, apoptotic volume decrease; cAMP, cyclic AMP; GIP, glucose-dependent insulinotropic polypeptide; GLP-1, glucagon-like peptide 1; GPCR, G protein-coupled receptor; GSIS, glucose-stimulated insulin secretion; HAT, histone acetyltransferase; HDAC, histone deacetylase; $\mathrm{K}_{\mathrm{ATP}}$, ATP-sensitive potassium channel; Kv, voltage-gated potassium channel; MSK-1, mitogen- and stress-activated kinase-1; PKA, protein kinase A; PTM(s), posttranslational modification(s); STS, staurosporine; TEA, tetraethylammonium; Thap, thapsigargin; TSA, Trichostatin A

Received 07.4.11; revised 13.6.11; accepted 23.6.11; Edited by JA Cidlowski; published online 05.8.11
} 
Bax expression ${ }^{4}$ and phosphorylation of apoptosis signal regulating kinase 1 (ASK1), resulting in sustained suppression of p38 MAPK and Jun N-terminal kinase. ${ }^{6}$ Intriguingly, in neurons, an apoptotic surge of $\mathrm{K}^{+}$current involves ASK1 and p38 MAPK. ${ }^{8,9}$

$\mathrm{Kv}$ channels are involved in the repolarization of excitable cells, and electrophysiological studies in human and rodent pancreatic $\beta$-cells have demonstrated their importance in the secretory process. ${ }^{10,11}$ Members of the Kv1, Kv2 and Kv3 families are thought to have important roles in insulin secretion by modulating the amplitude and duration of action potentials. $^{10,12}$ Although Kv1.4 channel conductance is an important component of transient outward current $\left(l_{\text {to }}\right)$, other subtypes of $\mathrm{Kv}$ channels contribute to delayed rectifier currents $\left(I_{\mathrm{DR}}\right)$ in $\beta$-cells, ${ }^{10,12,13}$ with Kv2.1 probably having the major role. ${ }^{10,12,13}$ In addition to regulating cell excitability, $\mathrm{K}^{+}$channels are involved in the initiation and progression of apoptosis in several different cell types. ${ }^{14,15}$ Increases in both conductance and surface expression of $\mathrm{Kv}$ channels contribute to neuronal apoptosis. Neuroprotective effects of expressing dominant-negative Kv2.1 in cortical neurons were associated with reduced $\mathrm{K}^{+}$current density following exposure to apoptotic stimuli, and trafficking of Kv2.1 channels to the plasma membrane was a major contributor to the initiation of apoptosis. ${ }^{16}$ In the current studies, prosurvival effects of GIP and GLP-1 were found to involve post-translational modifications (PTMs) of Kv2.1 by phosphorylation and acetylation, the latter process occurring via a novel pathway involving nuclear to cytoplasmic translocation of the lysine acetyl transferase, CREB binding protein (CBP).

\section{Results}

Kv channels are involved in STS- or Thapsigargininduced $\beta$-cell apoptosis and GIP/GLP-1 reduces Kv2.1mediated apoptotic cell death. The potential involvement of $\mathrm{K}^{+}$channels in $\beta$-cell apoptosis was investigated by examining the attenuation of channel conductance through treatment with the $\mathrm{K}^{+}$channel blocker tetraethylammonium (TEA) and quantifying apoptotic cell death in response to STS, an activator of mitochondria-mediated apoptosis, or Thapsigargin (Thap), an inducer of endoplasmic reticulum (ER) stress. As shown in Figures 1a and b, TEA reduced the levels of STS- and Thap-induced apoptosis in $\beta$-INS-1 (832/13) cells in a concentration-dependent manner. Additionally, TEA decreased STS-induced $\beta$-INS-1 cell death (Supplementary Figure 1).

In order to examine their potential involvement in $\beta$-cell apoptosis, Kv2.1, Kv1.5 and Kv3.2, channel proteins that are strongly expressed in $\beta$-cells ${ }^{10}$ (S Kim et al., unpublished), were transiently overexpressed in $\beta$-INS-1 cells. As shown in Supplementary Figure 2, Thap-induced $\beta$-cell death was significantly increased by overexpression of Kv2.1 and Kv1.5 but not by Kv3.2. In view of the more robust induction of $\beta$-cell death by Kv2.1, and evidence supporting the contribution of Kv2 channel family members to $\sim 60 \%$ of $\beta$-cell $\mathrm{I}_{\mathrm{DR}},{ }^{12}$ we focused further on the apoptotic effects of Kv2.1 in $\beta$-cells. As Kv2.1 expression is significantly lower in INS-1 (832/13) $\beta$-cells than in primary $\beta$-cells, for subsequent overexpression studies transfection conditions were optimized to mimic the Kv2.1 protein levels in human islets (Supplementary Figure $3 A)$. This resulted in a marked potentiation of both STS- and Thap-induced $\beta$-cell apoptosis (Figures $1 \mathrm{c}$ and $\mathrm{d}$ ) and $\beta$-cell death (Figures 1e and f).

We next examined the effects of GIP and GLP-1 on Kv2.1mediated $\beta$-cell apoptosis. Incubation of cells with Thap resulted in $\sim 4.5$-fold increase in apoptosis and this was reduced by $44.8 \%$ and $51.6 \%$ with GIP or GLP-1 treatment, respectively (Figure 2a). Similar results were obtained for $\beta$-cell death (Figure $2 \mathrm{~b}$ ). Despite the elevated levels of apoptosis in Kv2.1-overexpressing $\beta$-INS-1 cells, GIP and GLP-1 were both capable of reducing apoptotic cell death to levels below those observed with pcDNA-transfected cells treated with Thap, indicating that part of their effect was mediated via effects on $\mathrm{Kv}$ channel surface protein levels or conductance. To establish the functional involvement of endogenously expressed Kv2.1 in apoptosis, RNA interference was employed. As shown in Figure $2 c$ and Supplementary Figure 3B, RNAi-mediated knockdown resulted in specific reductions in Kv2.1 expression, associated with greatly reduced Thap-induced $\beta$-cell apoptosis. Both GIP and GLP-1 tended to further decrease the Thap-induced $\beta$-cell apoptosis, although the reduction did not reach statistical significance. Taken together, these results strongly support a role for Kv2.1 in Thap-induced apoptotic cell death and its involvement in GIP/GLP-1-mediated protection.

GIP and GLP-1 increase phosphorylation and acetylation of Kv2.1 in pancreatic $\beta$-cells. In earlier studies, both GIP ${ }^{11}$ and GLP $-1^{10}$ were found to increase $\mathrm{Kv}$ channel phosphorylation. Recently, reversible protein lysine acetylation has also been demonstrated to be a common PTM of non-nuclear proteins. ${ }^{17}$ As GIP and GLP-1 were both shown to be capable of stimulating histone acetylation, ${ }^{18}$ the effects of these incretins on levels of phosphorylated and acetylated Kv2.1 were examined. Transfected INS-1 $\beta$-cells were treated with GIP or GLP-1 and solubilized extracts immunoprecipitated with phosphoserine/threonine or acetyl-lysine antibodies, followed by immunoblotting with Kv2.1 antibody. GIP (1-42, $100 \mathrm{nM})$ and GLP-1 (7-36, $100 \mathrm{nM})$ increased phosphorylation (Figures $3 a$ and $b$ ) and acetylation (Figures $3 c$ and $d$ ) of Kv2.1, whereas truncated forms of the peptides, GIP (19-30) and GLP-1 (9-36), that do not exhibit insulinotropic activity, had no effect. These results indicate that the incretin hormones are capable of increasing both phosphorylation and acetylation of Kv2.1 protein in pancreatic $\beta$-cells.

PKA/mitogen- and stress-activated kinase-1 (MSK-1) and histone acetyltransferase (HAT)/histone deacetylase (HDAC) enzymes are involved in incretin-mediated PTM of Kv2.1 and promotion of $\beta$-cell survival. Signaling modules potentially involved in promoting PTM of Kv2.1 channels were next examined, initially focusing on pathways previously demonstrated to mediate incretin actions. ${ }^{2,3}$ GIP and GLP-1-stimulated Kv2.1 phosphorylation was greatly reduced or ablated by $\mathrm{H}-89(10 \mu \mathrm{M})$, an inhibitor of both PKA and MSK-1, as well as the specific competitive inhibitor of cAMP binding to the regulatory subunit of PKA, Rp-cAMPs 

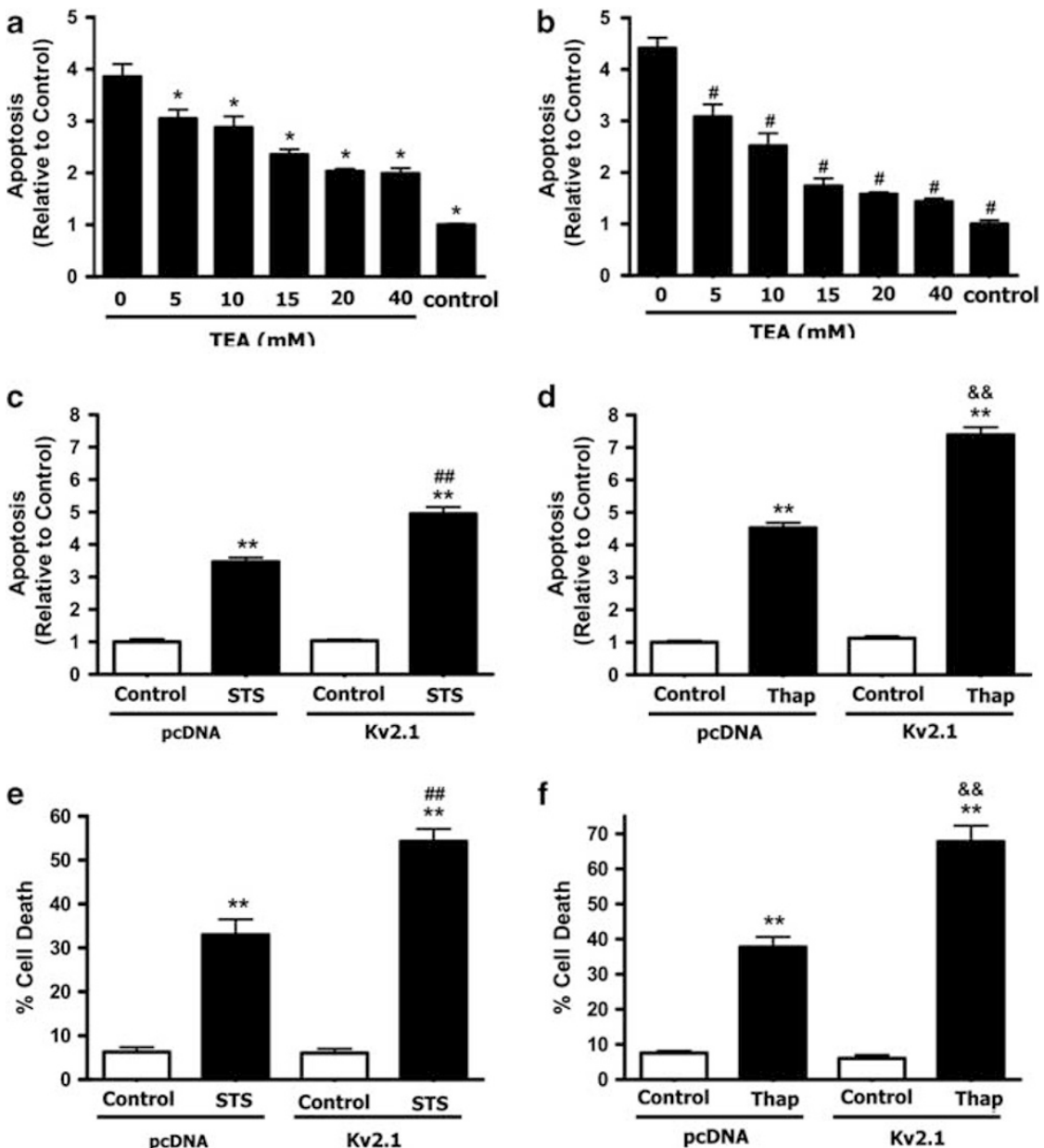

Figure $1 \mathrm{~K}^{+}$channels contribute to STS- and Thap-induced apoptosis in INS-1 $\beta$-cells ( $\mathbf{a}$ and $\left.\mathbf{b}\right)$. Effect of TEA on STS or Thap-induced INS-1 $\beta$-cell apoptosis. $\beta$-INS-1 $(832 / 13)$ cells were treated with STS $(100 \mathrm{nM}, \mathbf{a})$ or Thap $(1 \mu \mathrm{M}, \mathbf{b})$ in the presence or absence of TEA $(0$ to $40 \mathrm{mM})$ for $6 \mathrm{~h}$ and apoptotic cells were determined using the APOPercentage apoptosis assay kit as described in Materials and methods. (c-f). Effect of Kv2.1 overexpression on STS- or Thap-induced apoptotic cell death. INS-1 (832/13) $\beta$-cells were transfected with Kv2.1 or pcDNA3 and treated with STS ( $100 \mathrm{nM}, \mathbf{c}$ and $\mathbf{e})$ or Thap $(1 \mu \mathrm{M}, \mathbf{d}$ and $\mathbf{f})$ for $6 \mathrm{~h}$. $\beta$-cell apoptosis (c and $\mathbf{d})$ and $\beta$-cell death (e and f) were determined as described in Materials and Methods. Significance was tested using ANOVA with Newman-Keuls post hoc test; " ${ }^{*}$ epresents $P<0.05$ versus STS alone, ${ }^{\#}$ represents $P<0.05$ versus Thap alone, ${ }^{*}{ }^{*}$ represents $P<0.05$ versus pcDNA Control, ${ }^{\#}$ represents $P<0.05$ versus pcDNA plus STS, and ${ }^{\text {\& }}$ represents $P<0.05$ versus pcDNA plus Thap

$(200 \mu \mathrm{M})$ (Figure $4 \mathrm{a})$. Acetylation of Kv2.1 in response to GIP and GLP-1 was also greatly reduced by $\mathrm{H}-89$ and Rp-cAMPs, as well as by an inhibitor of HAT (HAT inhibitor II (HATII); $40 \mu \mathrm{M})$. Conversely, the HDAC inhibitor, Trichostatin A (TSA; $300 \mathrm{nM}$ ), mimicked the effects of GIP and GLP-1 on the acetylation of Kv2.1 (Figure 4b), as well as potentiated the level of incretin-induced Kv2.1 acetylation. As expected, neither the HAT nor the HDAC inhibitor affected Kv channel phosphorylation (Figure 4a). To determine whether phosphorylation and acetylation of Kv2.1 contribute to GIP and GLP-1-mediated $\beta$-cell survival, Thap-induced $\beta$-cell apoptosis was determined in the absence or presence of PKA/MSK-1, PKA and HAT/HDAC inhibitors. As shown in Figure $4 \mathrm{c}$, incretin-mediated $\beta$-cell survival was greatly reduced by $\mathrm{H}-89$, Rp-cAMPs and HAT inhibitor II. In contrast, the HDAC inhibitor potentiated the effects of GIP and GLP-1 on $\beta$-cell survival. Together, these results demonstrate that pathways involving PKA/MSK-1 and HAT/ HDAC are involved in incretin-mediated PTMs of Kv2.1 associated with $\beta$-cell survival.
GIP and GLP-1 regulate the nuclear/cytoplasmic localization of CBP. In view of the recent demonstration that cytoplasmic CBP was capable of acetylating the prolactin $^{\text {receptor }}{ }^{19}$ and the relative selectivity of HAT inhibitor II for CBP/p300, we examined the effects of GIP and GLP-1 on the cellular distribution of CBP. As shown in Figures $5 \mathrm{a}, \mathrm{b}$ and e, GIP or GLP-1 treatment of INS-1 $\beta$-cells decreased nuclear, and increased cytoplasmic, localization of CBP. These responses were apparent $15 \mathrm{~min}$ after initiation of GIP or GLP-1 treatment and thereafter sustained to $120 \mathrm{~min}$, returning towards basal by $1200 \mathrm{~min}$. Subsequent studies demonstrated a GIP/GLP-1 concentration dependence for nuclear/cytoplasmic shuttling of CBP (Figures $5 c$, $d$ and $f$ ) and observed similar responses with human pancreatic islets (Figures $5 \mathrm{~g}$ and $\mathrm{h}$ ). Immunocytochemical staining of INS-1 $\beta$-cells confirmed the effects of incretins on nuclear CBP translocation detected by western blotting (Figure $5 \mathrm{i}$ ). On the other hand, GIP and GLP-1 were without effect on the nuclear/cytoplasmic distribution of p300 (Figures 5j and k), a CREB-related 
adaptor protein that shares high sequence homology with $\mathrm{CBP}$ and exerts both common and unique transcriptional activities. $^{20}$

CBP mediates GIP and GLP-1-induced acetylation of Kv2.1, resulting in channel internalization. As GIP and
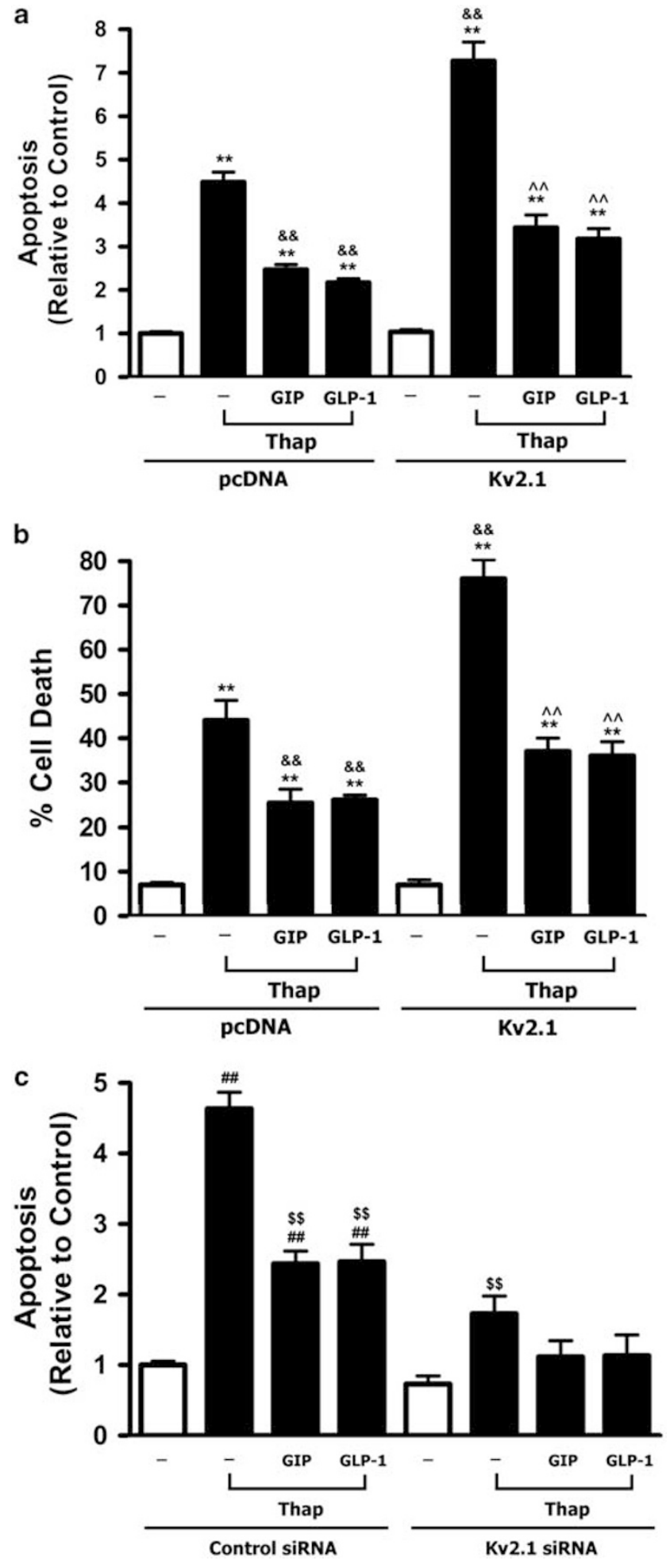

GLP-1 increased the cytoplasmic localization of CBP, its role in GIP and GLP-1-mediated acetylation of Kv2.1 was examined. As shown in Figure 6a, in co-immunoprecipitation experiments, protein-protein interactions between CBP and Kv2.1 were observed in GIP or GLP-1treated human islets. To establish the functional importance of CBP in GIP/GLP-1-mediated regulation of Kv2.1, RNA interference was employed. RNAi-mediated knockdown resulted in greatly reduced nuclear CBP expression in INS-1 $\quad \beta$-cells (Figure 6b). Co-immunoprecipitation experiments demonstrated that CBP knockdown almost completely ablated GIP or GLP-1-induced lysine acetylation of Kv2.1 (Figure 6c) and greatly reduced protein-protein interactions between CBP and Kv2.1 (Figure 6d). Translocation of CBP from the nucleus is therefore likely to be an important mediator of GIP- and GLP-1-induced lysine acetylation of Kv2.1.

GIP-induced phosphorylation of Kv1.4 was previously demonstrated to result in endocytosis, ${ }^{11}$ and Kv2.1 trafficking to the plasma membrane was shown to be responsible for increases in $\mathrm{K}^{+}$currents associated with neuronal apoptosis. ${ }^{16}$ We therefore determined whether GIP/GLP-1-mediated regulation of Kv2.1 involves channel protein internalization. Incubating cells with proteinase $\mathrm{K}$ randomly cleaves the extracellular regions of proteins, thus producing digested forms, whereas intracellular protein is protected. Using this technique, surface membrane expression levels of Kv2.1 in human islets were shown to decrease in response to treatment with GIP $(1-42,100 \mathrm{nM})$ or GLP-1 $(7-36,100 \mathrm{nM})$ (Figure 6e). As cellular $\mathrm{K}^{+}$efflux has been shown to be a central step for the progression and completion of apoptotic cell death in numerous cell types, incretin-mediated Kv2.1 PTM and internalization are likely to be critical for $\beta$-cell survival.

\section{Discussion}

Although a role for Kv channels in the regulation of membrane repolarization and insulin secretion in pancreatic $\beta$-cells is established, their involvement in $\beta$-cell apoptosis has not been previously reported. It has been demonstrated in several cell

Figure 2 GIP and GLP-1 reduce apoptosis potentiated by Kv2.1 overexpression. (a) Effects of GIP and GLP-1 on Thap-induced INS-1 $\beta$-cell apoptosis. INS-1 (832/13) $\beta$-cells were transfected as described above and treated with Thap $(1 \mu \mathrm{M})$ for $6 \mathrm{~h}$ in the presence or absence of GIP $(1-42,100 \mathrm{nM})$ or GLP-1 (7-36, $100 \mathrm{nM}$ ). Apoptotic cells were quantified using the APOPercentage apoptosis assay kit. (b) Effects of GIP and GLP-1 on Thap-induced INS-1 $\beta$-cell death. INS-1 $\beta$-cells were treated as described above and $\beta$-cell death was measured using a highthroughput CellomicsArrayscan V automated imager, as described in Materials and Methods. (c) Effect of Kv2.1 siRNA on Thap-induced INS-1 $\beta$-cell death. INS-1 $\beta$-cells were transfected with Kv2.1 siRNA or Control scrambled siRNA (100 nM), and incubated for $72 \mathrm{~h}$, as described in Materials and methods. Cells were treated with Thap $(1 \mu \mathrm{M})$ for $6 \mathrm{~h}$ in the presence or absence of GIP $(1-42,100 \mathrm{nM})$ or GLP-1 $(7-36,100 \mathrm{nM})$. Apoptotic cells were quantified using the APOPercentage apoptosis assay kit. Significance was tested using ANOVA with Newman-Keuls post hoc test, where ${ }^{* *}$ represents $P<0.05$ versus pcDNA Control, ${ }^{\text {\& }}$ represents $P<0.05$ versus pcDNA plus Thap, Mrepresents $P<0.05$ versus Kv2.1 plus Thap, \#\# represents $P<0.05$ versus Control siRNA, and ${ }^{\$ \$}$ represents $P<0.05$ versus Control siRNA plus Thap 
a

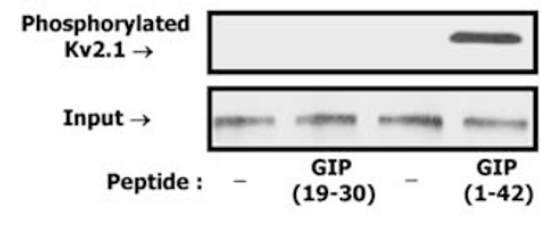

b

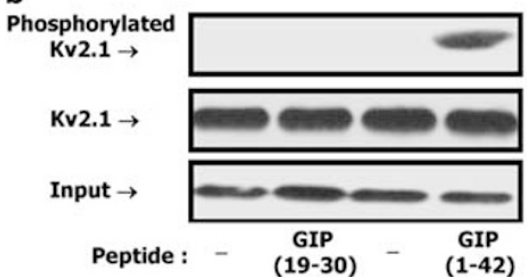

C Acetylated
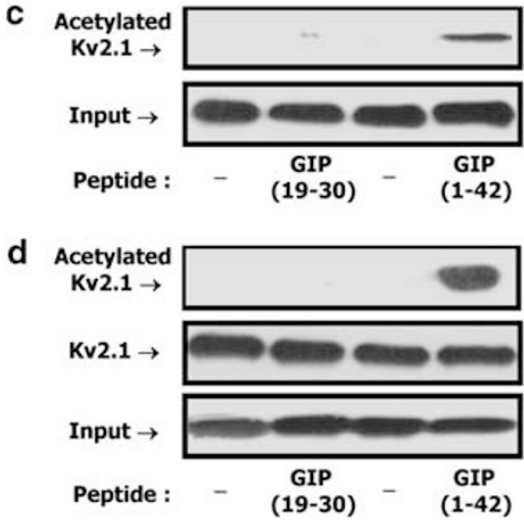

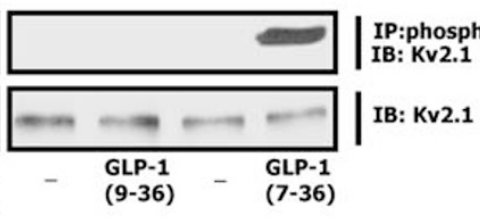

IB: $K v 2.1$
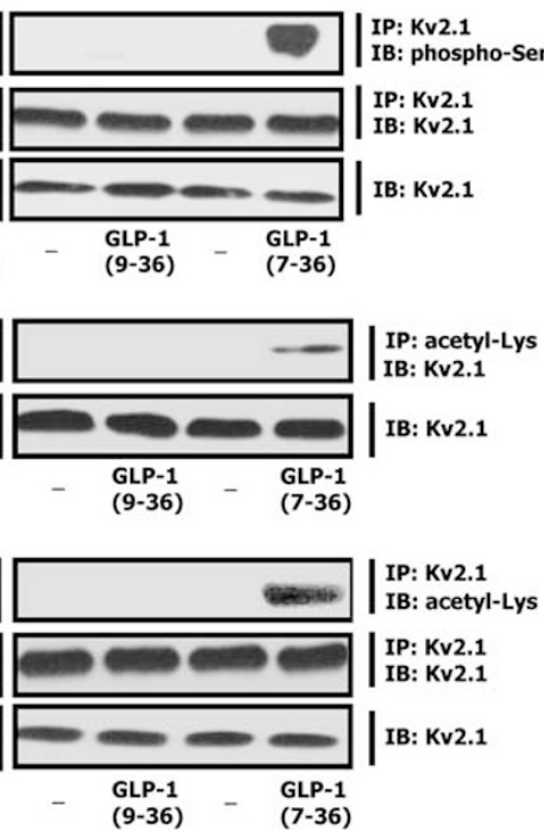

Figure 3 GIP and GLP-1 increase phosphorylation and acetylation of Kv2.1. (a-d) Effect of GIP/GLP-1 on phosphorylation and acetylation of Kv2.1. INS-1 $\beta$-cells were transfected with Kv2.1 and incubated with $100 \mathrm{nM}$ of indicated peptides, GIP (1-42), GIP analog (19-30), GLP-1 (7-36) or GLP-1 analog (9-36) for $1 \mathrm{~h}$. Total cellular protein extracts were isolated from each sample and immunoprecipitated (IP) with phospho-Ser/Thr (a), Kv2.1 (b and d) or acetyl-Lys (c) followed by immunoblotting (IB) for Kv2.1 (a and $\mathbf{c}$ ), phospho-Ser/Thr (b) or acetyl-Lys (d). Input represents one-tenth of total protein extract used in the Co-IP assay. Western blots are representative of $n=3$

types that apoptotic cell shrinkage (apoptotic volume decrease; AVD) occurs early in the process, before ultrastructural and biochemical changes, such as DNA fragmentation, cytochrome $c$ release and caspase 3 activation, ${ }^{14}$ and is a prerequisite for completion of programmed cell death. Ionic mechanisms involved in AVD are complex, but $\mathrm{K}^{+}$is the major cytoplasmic cation responsible for maintaining cell volume ${ }^{14,21,22}$ and efflux of $\mathrm{K}^{+}$is a critical component of the AVD. ${ }^{21}$ Indeed, activities of a number of caspases and endonucleases are suppressed at normal intracellular $\mathrm{K}^{+}$ levels and one of the main early events in apoptosis results from decreases in its intracellular concentration, allowing their activation. ${ }^{22} \mathrm{~A}$ number of different $\mathrm{K}^{+}$channels have been implicated in AVD, including Kv family members, ${ }^{14,16,21,22}$ and treatment with the $\mathrm{K}^{+}$channel blockers TEA and 4-AP inhibits apoptosis in various cell types. ${ }^{21}$

In earlier studies, GIP and GLP-1 receptor activation was demonstrated to potentiate GSIS by modulating Kv channels, ${ }^{11,23-25}$ and both incretins exert beneficial effects on $\beta$-cell survival. ${ }^{2-6}$ The current study was therefore initiated in order to test the hypothesis that GIP's and GLP-1's actions on $\mathrm{K} v$ channels are linked to effects on $\beta$-cell survival. In rodent primary $\beta$-cells, $>80 \%$ of the outward $\mathrm{K}^{+}$currents are generated by channels that are sensitive to the blocker TEA. ${ }^{24}$
Treatment of $\beta$-INS-1 cells with TEA greatly reduced apoptosis induced by STS or Thap treatment (Figures 1a and $\mathrm{b}$ ), suggesting the involvement of $\mathrm{K}^{+}$channels. In addition to direct actions on $\mathrm{K}^{+}$channels, TEA has been suggested to act on other cation channels in HeLa cells and by reducing cytochrome $c$ release from mitochondria, ${ }^{26}$ and we cannot rule out their contribution to $\beta$-cell responses.

Kv2.1 has an important role in $\beta$-cell repolarization. ${ }^{12,23}$ Additionally, the cytoplasmic C-terminus of Kv2.1 binds to syntaxin $1 \mathrm{~A}$ in $\beta$-cells and their interaction is involved in channel gating, trafficking and insulin exocytosis. ${ }^{27,28}$ Multifunctional roles have also been shown in other cell types, and Kv2.1 facilitation of secretory vesicle recruitment in neuroendocrine cells, ${ }^{29}$ and the clustering of cell surface Kv2.1 channels in hippocampal neurons ${ }^{30}$ were shown to be independent from $\mathrm{K}^{+}$conductance. In view of its additional pro-apoptotic role in neurons, we focused on the potential role of Kv2.1 in $\beta$-cell apoptosis and the ability of GIP and GLP-1 to modulate its action. Expression of Kv2.1 protein in $\beta$-INS- 1 cells, at levels similar to those found in human $\beta$-cells, strongly potentiated apoptotic responses to both STS and Thap (Figures 1c-f, $2 \mathrm{a}$ and $b$ ), whereas RNAi-mediated knockdown of endogenous Kv2.1 attenuated Thap-induced apoptosis (Figure 2c). These findings supported a role for Kv2.1 in $\beta$-cell apoptosis. 
a

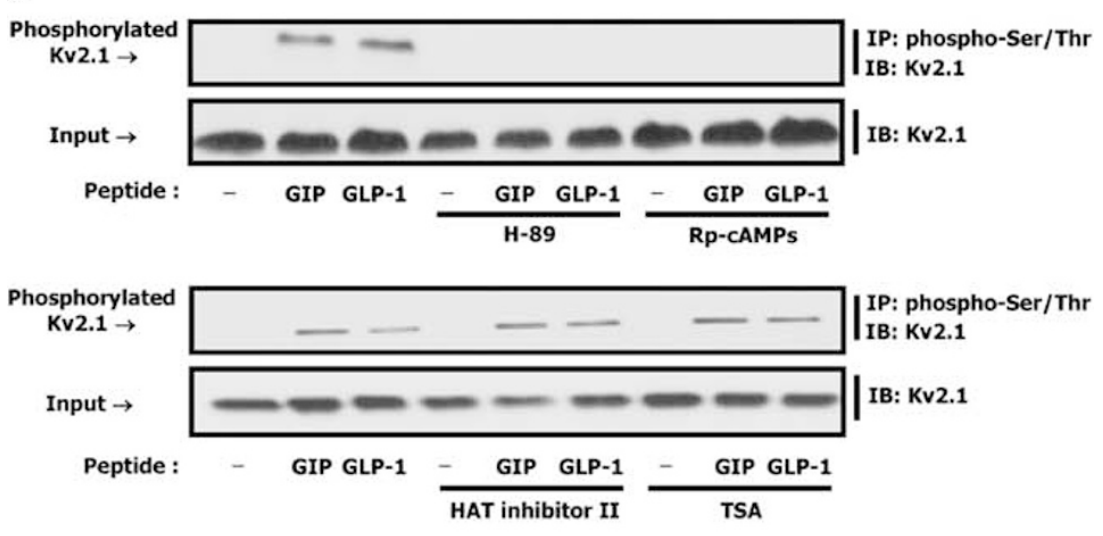

b

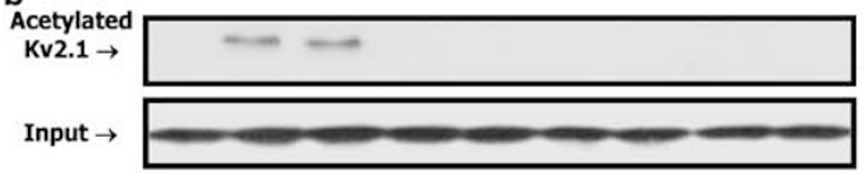

IP: acetyl-Lysine IB: Kv2.1

Peptide :

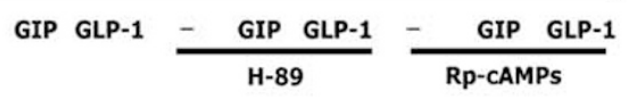

IB: Kv2.1
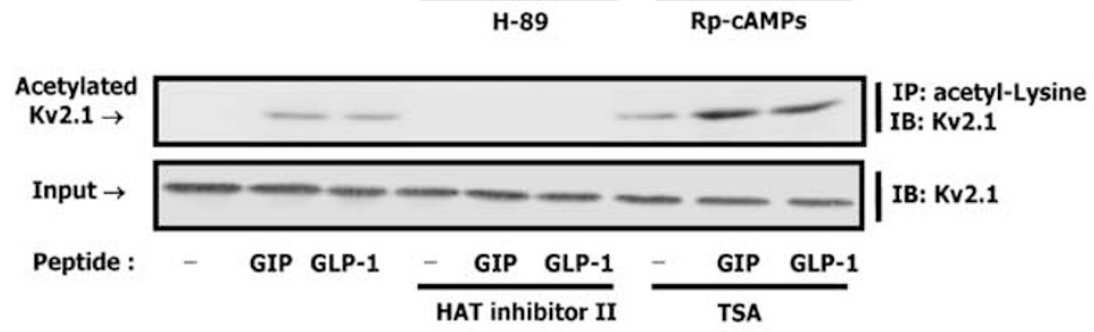

c

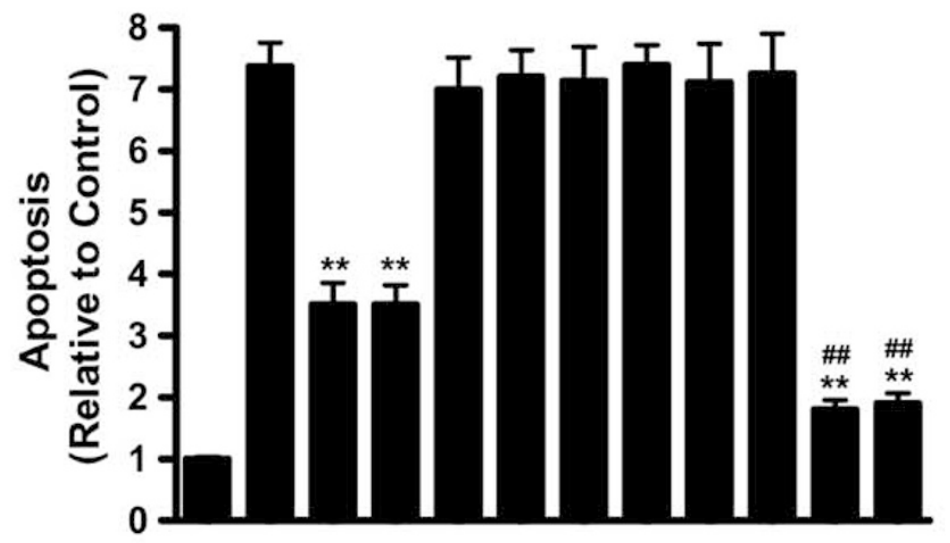

\begin{tabular}{|l|c|c|c|c|c|c|c|c|c|c|c|c|}
\hline Thap & - & + & + & + & + & + & + & + & + & + & + & + \\
\hline GIP & - & - & + & - & + & - & + & - & + & - & + & - \\
\hline GLP-1 & - & - & - & + & - & + & - & + & - & + & - & + \\
\hline H-89 & - & - & - & - & + & + & - & - & - & - & - & - \\
\hline Rp-cAMPS & - & - & - & - & - & - & + & + & - & - & - & - \\
\hline HAT inhibitor II & - & - & - & - & - & - & - & - & + & + & - & - \\
\hline TSA & - & - & - & - & - & - & - & - & - & - & + & + \\
\hline
\end{tabular}


Modulation of channel conductance has been considered to be the major effect of GLP-1 receptor activation on $\beta$-cell Kv2.1. ${ }^{24,25}$ However, the pro-apoptotic effects of Kv2.1 overexpression in $\beta$-INS-1 cells were strongly reduced by both incretin hormones (Figure 2a). A number of voltagegated $\mathrm{K}^{+}$channel proteins are regulated by serine/threonine phosphorylation, ${ }^{11,25,31}$ and both phosphorylation ${ }^{25}$ and SUMOylation $^{32}$ of Kv2.1 modulate channel conductance in pancreatic $\beta$-cells. In mass spectrometry-based assays multiple phosphorylation sites were identified in Kv2.1 ${ }^{31}$ and, among these, p38 MAPK-mediated phosphorylation of Kv2.1 at Ser800 is involved in Kv2.1 trafficking to the plasma membrane during neuronal apoptosis. ${ }^{33}$ An Src family tyrosine kinase was shown to constitutively activate $\mathrm{Kv} 2.1{ }^{34}$ and Tyr124 of Kv2.1, a target for Src kinase, is critical for the neuronal apoptotic surge. ${ }^{35}$ Additionally, downregulation of Kv2.1, via the cAMP/PKA signaling pathway, reduced apoptosis in cerebellar granular neurons. ${ }^{36}$

Lysine acetylation of proteins has recently been identified as a PTM of widespread importance, linked to the modulation of cytoskeleton dynamics, endocytosis, autophagy and energy metabolism, ${ }^{20,37}$ and $>80$ transcription factors and nuclear regulators, as well as various cytoplasmic proteins, have been identified as acetyltransferase targets. ${ }^{38}$ As both GIP and GLP-1 act via stimulation of protein kinase cascades $^{1-3}$ and also increase histone acetylation, ${ }^{18}$ the potential involvement of both PTMs of Kv2.1 was investigated and shown to occur in INS-1 $\beta$-cells (Figures 3a-d). Incretinmediated phosphorylation of Kv2.1 was greatly reduced by $\mathrm{H}-89$ and Rp-cAMPs, whereas inhibitors of HAT/HDAC were without effect (Figures $4 a$ and b). On the other hand, acetylation of Kv2.1 was greatly reduced by $\mathrm{H}-89$, Rp-cAMPs and HAT/HDAC inhibitors. Although Rp-cAMPs is a relatively specific inhibitor of PKA, H-89 also strongly inhibits both GIP and GLP-1 stimulation of phosphorylation of MSK-1 at Ser376, mediated by PKA, and MSK-1 enzymatic activity in INS-1 $\beta$-cells. ${ }^{18}$ It is therefore plausible that both PKA and MSK-1 are involved in incretin-mediated PTMs of $\mathrm{Kv}$ channels. As incretin-mediated $\beta$-cell survival was greatly reduced by HAT inhibitor II and the HDAC inhibitor potentiated the effects of GIP/GLP-1 on $\beta$-cell survival (Figure $4 c$ ), without affecting incretin-mediated Ser/Thr phosphorylation of Kv2.1 (Figure 4a), acetylation seems to be the more critical incretinmediated PTM of Kv2.1 associated with $\beta$-cell survival. However, it is still possible that PKA-mediated phosphorylation is a prerequisite step for acetylation of Kv2.1, as incretinmediated acetylation of Kv2.1 was greatly reduced by $\mathrm{H}-89$ and Rp-cAMPs treatment (Figure 4b).

Cytosolic acetyltransferase and deacetylase enzymes have not been extensively characterized. However, dimerization of the prolactin receptor was recently shown to be stimulated through acetylation by $\mathrm{CBP} / \mathrm{p} 300,{ }^{19}$ key regulators of $\mathrm{CREB}-$ mediated gene transcription, and both GIP and GLP-1 stimulate expression of multiple proteins via PKA activation of CREB-related pathways, ${ }^{1-3,5}$ as well as by stimulating histone lysine acetylation. ${ }^{18}$ We therefore investigated CBP and/or p300 involvement in GIP/GLP-1-stimulated lysine acetylation of Kv2.1. Surprisingly, GIP and GLP-1 induced extensive export of nuclear CBP to the cytoplasm (Figures $5 \mathrm{a}$ and b), whereas p300 was relatively unaffected, and both incretins also increased protein-protein interactions between CBP and Kv2.1 (Figure 6a). RNAi-mediated knockdown of CBP resulted in disruption of these interactions, as well as reduced acetylated Kv2.1 levels (Figures 6c and d), suggesting that CBP is a major acetyltransferase responsible for Kv2.1 acetylation. At present, nothing is known about the mechanisms underlying transport of acetylases or deacetylases between cytosolic and nuclear compartments. However, increased cytosolic levels of CBP were detected within $15 \mathrm{~min}$ of stimulation and levels were increased for up to $2 \mathrm{~h}$. Changes in the relative balance between acetylation and deacetylation have previously been shown to significantly impact on pancreatic $\beta$-cell death: inhibition of HDACs preventing cytokine-induced $\beta$-cell apoptosis and impairing $\beta$-cell function. ${ }^{39,40}$ As cellular $\mathrm{K}^{+}$efflux is a critical step in the apoptotic cell death program, incretin-mediated PTMs of Kv2.1 and associated internalization (Figure 6e) are therefore likely to be important for $\beta$-cell survival.

In summary, we have shown that GIP and GLP-1 modulate both phosphorylation and acetylation of Kv2.1, resulting in reduced surface expression, and that PKA/MSK-1 and HAT/ $\mathrm{HDAC}$ are involved in this process. The resultant decrease in $\mathrm{K}^{+}$efflux is likely an important factor in incretin-mediated prosurvival effects. However, both incretins also modulate the activities of intracellular mediators of apoptosis, including Ask1, Bax and Bad, as well as cytochrome $c$ release. As trafficking of CBP to the plasma membrane appears to be a major contributor to acetylation of Kv2.1, developing a better understanding of its regulation and the implications for regulation of gene expression is clearly important. This also appears to be the first example of GPCR-stimulated export of a nuclear lysine acetylase that regulates cell surface ion channel function. Altogether, our findings reveal an intriguing scenario whereby the release of nutrient-sensitive gut hormones couples to both functional and survival potentiating mechanisms in the $\beta$-cell via a signaling axis converging on voltage-sensitive ion channels that function to restore homeostasis following cellular excitation.

\section{Materials and Methods}

$\beta$-INS-1 cell culture and transient transfections. $\beta$-INS-1 cells (clone 832/13) were kindly provided by Dr. CB Newgard (Duke University, Durham, NC, USA).

Figure 4 PKA/MSK-1 and HAT/HDAC are involved in incretin-mediated PTMs of Kv 2.1 and $\beta$-cell survival. (a and $\mathbf{b})$ Effect of inhibiting PKA/MSK-1 or HAT/HDAC on PTMs of Kv 2.1. INS-1 $\beta$-cells were transfected with Kv2.1 and stimulated with $100 \mathrm{nM}$ of GIP (1-42) or GLP-1 (7-36) in the presence or absence of PKA/MSK-1 inhibitor, H-89 $(10 \mu \mathrm{M})$, a competitive inhibitor of PKA, Rp-cAMPs $(200 \mu \mathrm{M})$, HAT inhibitor, HAT inhibitor II (40 $\mu \mathrm{M})$ or HDAC inhibitor and Trichostatin A (TSA, $300 \mathrm{nM})$. Protein extracts were isolated from each sample and IP with phospho-Ser/Thr (a) or acetyl-Lys (b) followed by IB for Kv2.1. Input represents one-tenth of total protein extract used in the Co-IP assay. (c) Effect of inhibiting PKA/MSK-1 or HAT/HDAC on incretin-mediated $\beta$-cell survival. INS- $1 \beta$-cells were transfected with Kv2.1 and treated with Thap ( $1 \mu \mathrm{M})$ for 6 hs in the presence or absence of GIP (1-42, $100 \mathrm{nM})$, GLP-1 (7-36, GLP-1 (7-36), PKA/MSK-1 inhibitor, H-89 (10 $\mu \mathrm{M})$, a competitive inhibitor of PKA, Rp-cAMPs (200 $\mu \mathrm{M})$, HAT inhibitor, HAT inhibitor II $(40 \mu \mathrm{M})$, or HDAC inhibitor, Trichostatin A (TSA, $300 \mathrm{nM})$. Apoptotic cell death was determined using the APOPercentage apoptosis assay kit as described in Materials and methods. Significance was tested using ANOVA with Newman-Keuls post hoc test, where ${ }^{\star *}$ represents $P<0.05$ versus Thap, and ${ }^{\# \#}$ represents $P<0.05$ versus Thap plus GIP or GLP-1 
Cells were cultured in $11 \mathrm{mM}$ glucose RPMI 1640 (Sigma-Aldrich, Oakville, ON, Canada) supplemented with $2 \mathrm{mM}$ glutamine, $50 \mu \mathrm{M} \beta$-mercaptoethanol, $10 \mathrm{mM}$ HEPES, $1 \mathrm{mM}$ sodium pyruvate, $10 \%$ fetal bovine serum, $100 \mathrm{units} / \mathrm{ml}$ penicillin
G-sodium and $100 \mu \mathrm{g} / \mathrm{ml}$ streptomycin sulfate. Cell passages $45-75$ were used. Transient transfections were performed with Kv1.5, Kv2.1 or Kv3.2 or pcDNA3 plasmids using Lipofectamine 2000 reagent (Invitrogen, Carlsbad, CA, USA).
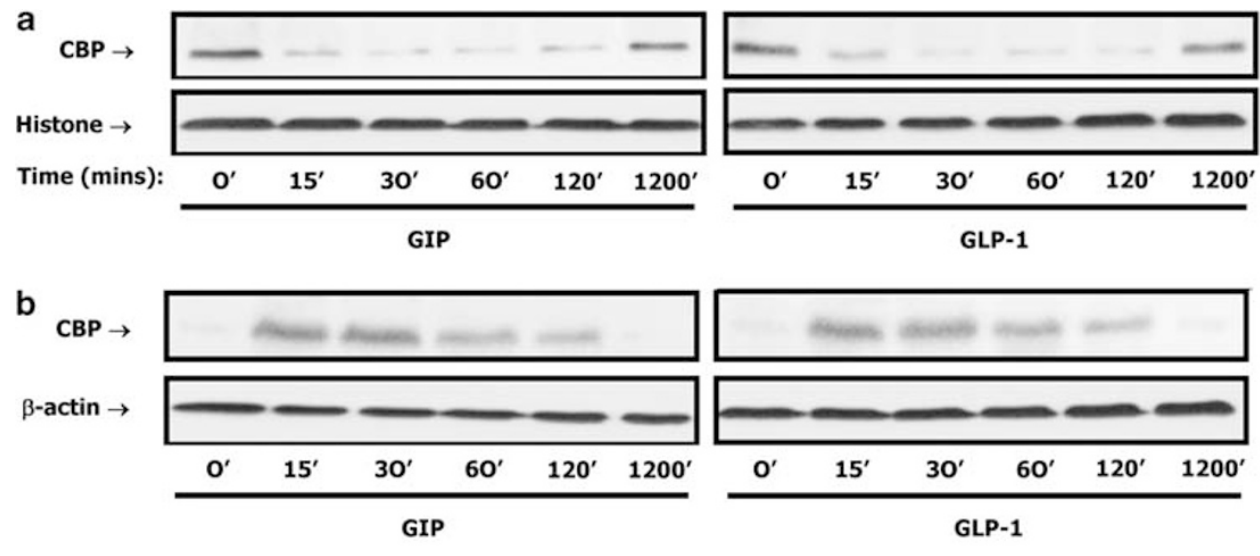

C
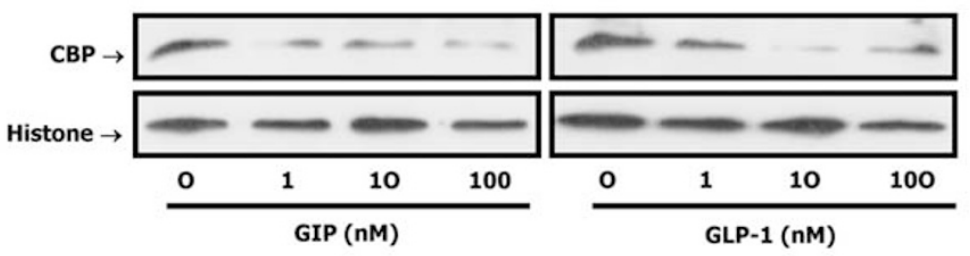

d
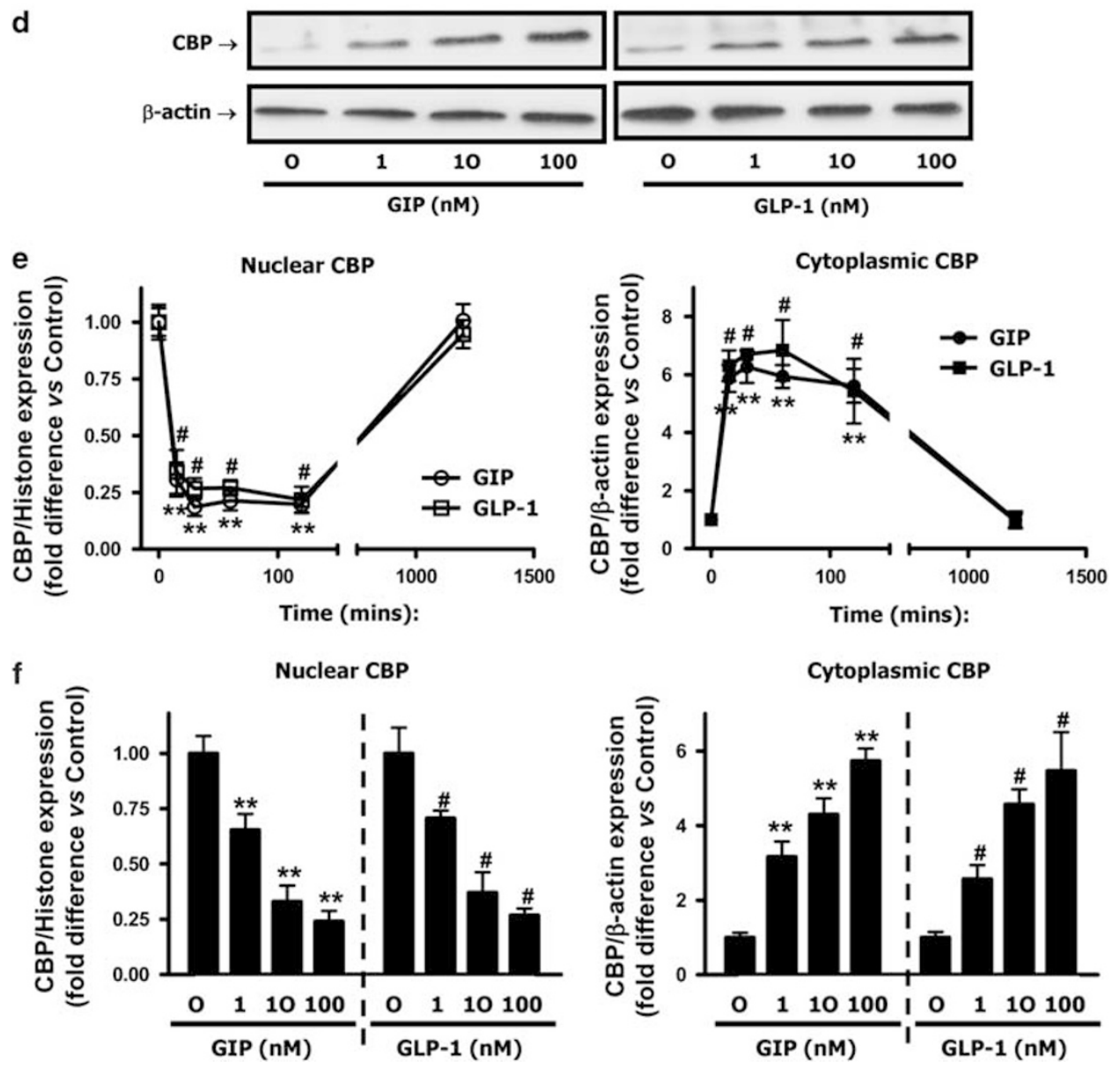

Figure 5 (continued) 

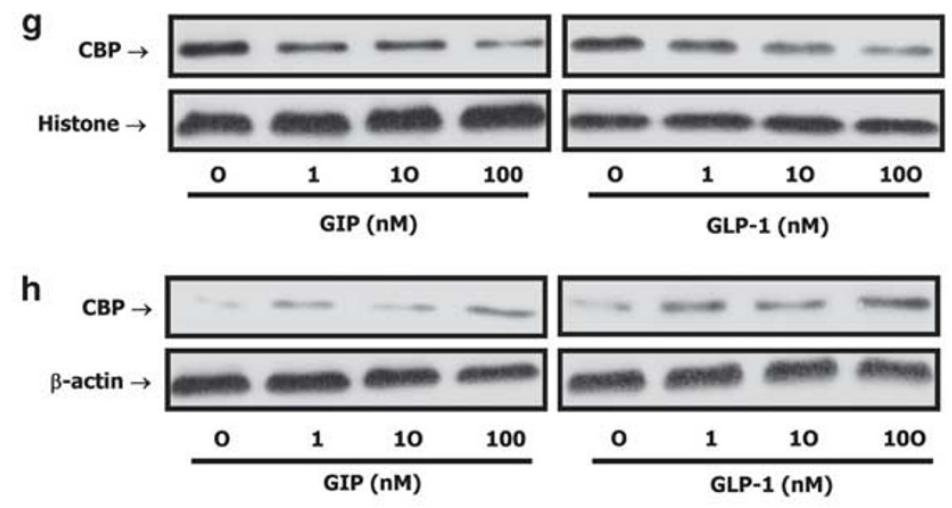

i
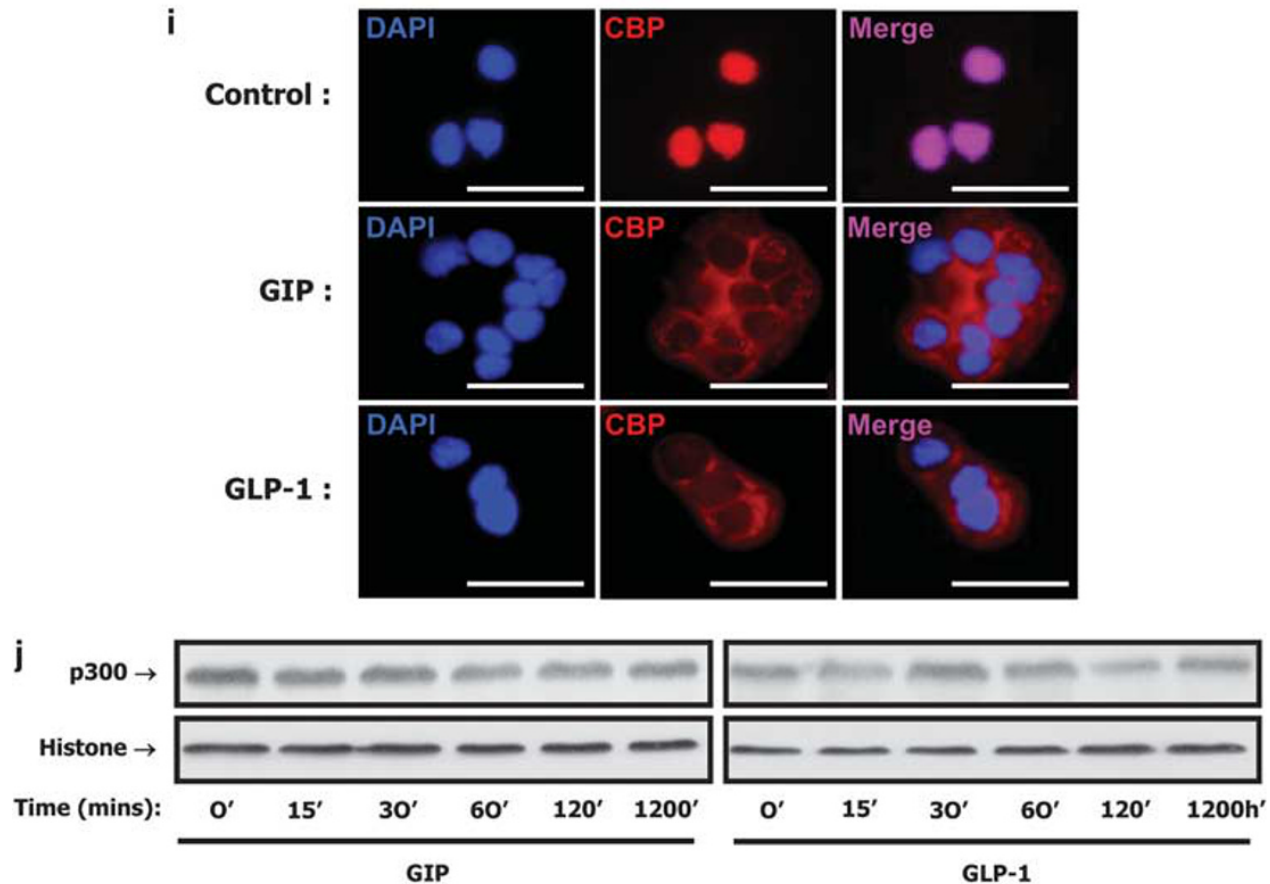

$\mathbf{k}$
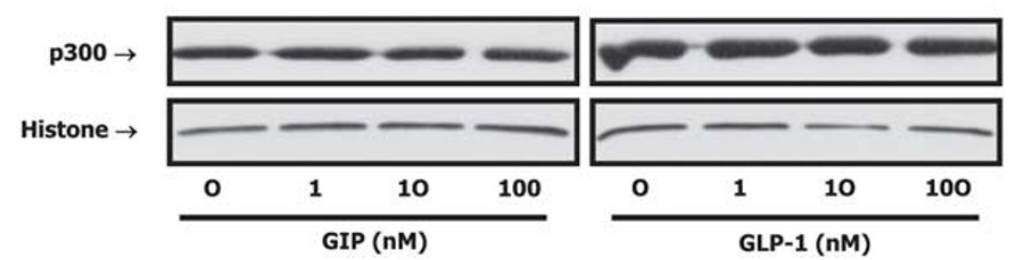

Figure 5 GIP and GLP-1 export nuclear CBP to cytoplasm. (a-d) Time course ( $\mathbf{a}$ and $\mathbf{b}$ ) and concentration-response effect (c and $\mathbf{d})$ of GIP/GLP-1 on nuclear (a and $\mathbf{c}$ ) and cytoplasmic ( $\mathbf{b}$ and $\mathbf{d}$ ) CBP. INS-1 $\beta$-cells were treated for the indicated periods of time with GIP or GLP-1 $(100 \mathrm{nM})$ in the time course studies, or for $1 \mathrm{~h}$ with varying concentrations of GIP or GLP-1 in the concentration-response studies. Western blot analyses were performed on nuclear (a and $\mathbf{c})$ or cytoplasmic $(\mathbf{b}$ and $\mathbf{d})$ fractions using antibodies against CBP, histone and $\beta$-actin. (e and $\mathbf{f})$ Densitometric analysis of $(\mathbf{a}-\mathbf{d})$. western blots were quantified and normalized with the loading control, histone or $\beta$-actin. Shown are fold differences versus Control. ( $\mathbf{g}$ and $\mathbf{h})$. Concentration-response effect of GIP/GLP-1 on nuclear (e) and cytoplasmic (f) CBP. Human islets were treated for $1 \mathrm{~h}$ with varying concentrations of GIP or GLP-1. Western blot analyses were performed on nuclear (e) or cytoplasmic (f) fractions using antibodies against CBP, histone and $\beta$-actin. (i) Confocal Microscopy. INS-1 $\beta$-cells were treated as described above and incubated with GIP or GLP-1 (100 nM) for $1 \mathrm{~h}$. Immunocytochemical staining was performed using antibodies against CBP (red) and nuclei were stained with DAPI (blue). The scale bar indicates $20 \mu \mathrm{m}$ and all imaging data were analyzed using the EZC1 software. ( $\mathbf{j}$ and $\mathbf{k}$ ) Time course effect (j) and concentration-response effect (k) of GIP/GLP-1 on nuclear p300. INS-1 $\beta$-cells were treated for the indicated periods of time with GIP or GLP-1 $(100 \mathrm{nM})$ in the time course studies, or for $1 \mathrm{~h}$ with varying concentrations of GIP or GLP-1 in the concentration-response studies. Western blot analyses were performed on nuclear fractions using antibodies against $\mathrm{p} 300$, histone and $\beta$-actin. Western blots are representative of $n=3$ and significance was tested using ANOVA with Newman-Keuls post hoc test, where ** represents $P<0.05$ versus GIP Control, " represents $P<0.05$ versus GLP-1 Control

Islet isolation and primary cell culture. Human islets were isolated from the pancreas of five adult organ donors using collagenase duct perfusion, dissociation and density gradient purification at the Ike Barber Islet Transplantation Laboratory (VGH, Vancouver, BC, Canada). The Research Ethics Board of UBC provided ethics approval.
Cell death assays and apoptosis. $\beta$-INS-1 cells were treated with STS $(100 \mathrm{nM})$ or Thap $(1 \mu \mathrm{M})$ for $6 \mathrm{~h}$ and cell death determined by counting propidium iodide-positive nuclei and total cell number measured by counting Hoechst 33342-positive nuclei. ${ }^{6}$ Fluorescent signals were quantified with high-throughput imaging systems, CellomicsArrayscan V 
a

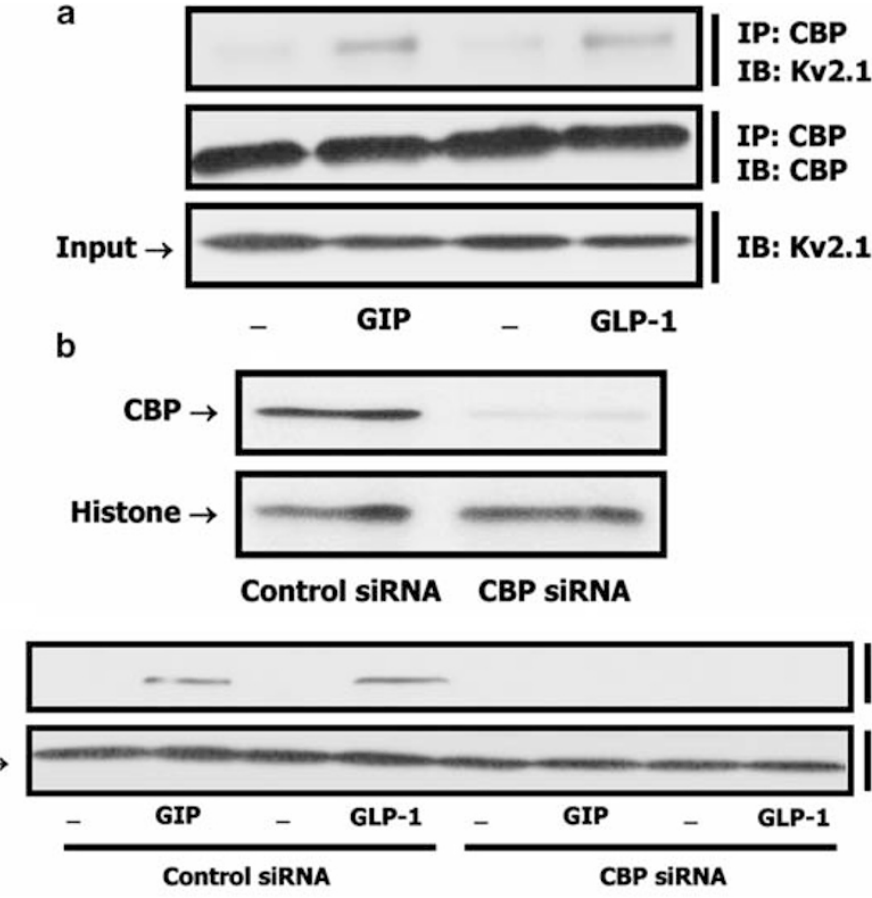

c

Input $\rightarrow$

d

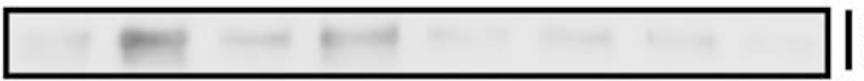

IP: CBP

IB: Kv2.1

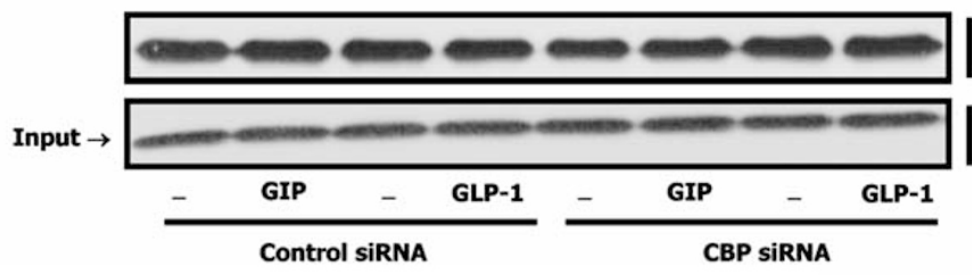

IP: CBP

IB: CBP

IB: Kv2.1
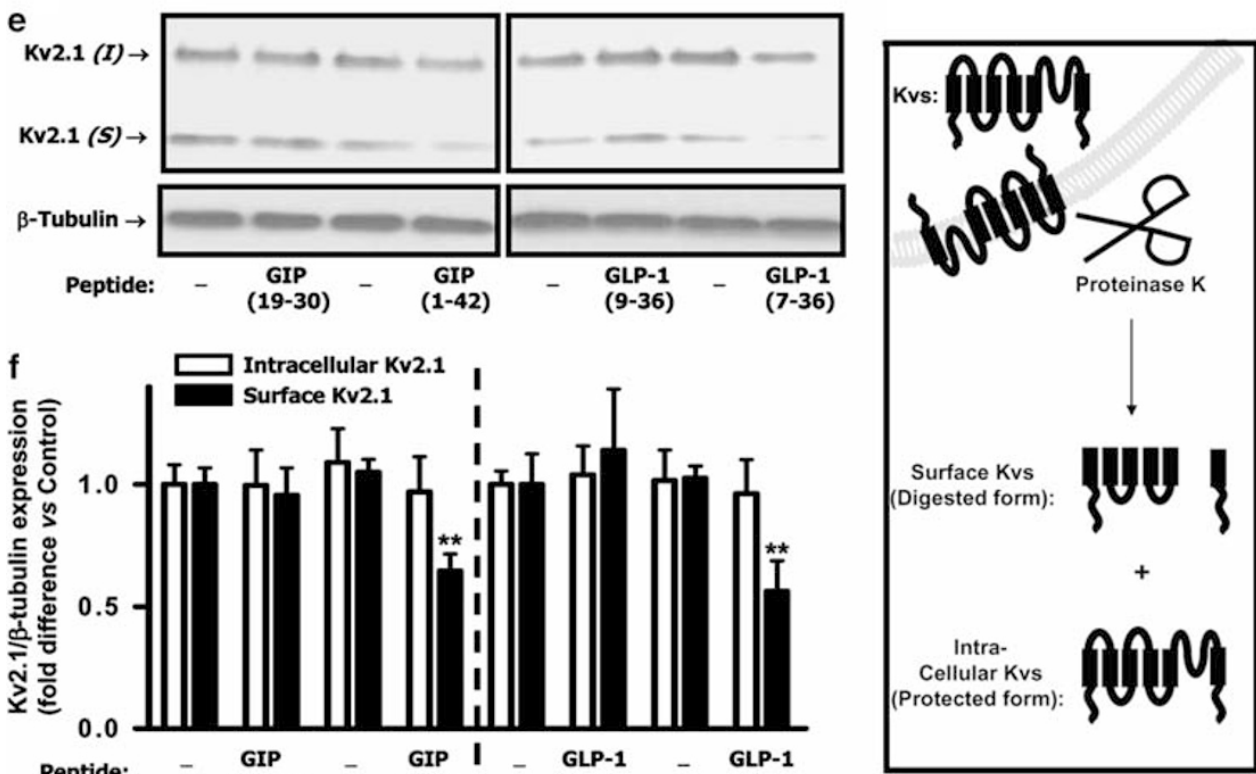

automated imager or Cellomics KineticScan (Cellomics Inc., Pittsburgh, PA, USA), and percent of cell death calculated. Detection of apoptotic cells was performed with the APOPercentage apoptosis assay kit (Biocolor Ltd, Belfast, Northern Ireland), based on specific uptake of dye by an apoptotic 'flip-flop' mechanism. APOPercentage dye was added to cells $30 \mathrm{~min}$ before completion of the apoptotic inducer/incretin incubation. Quantitative analysis was performed using a 
Figure 6 CBP is responsible for GIP/GLP-1-mediated acetylation of Kv2.1. (a) Co-immunoprecipitation (Co-IP). Human islets were treated with GIP or GLP-1 (100 nM) for 1 h. Cytoplasmic extracts were isolated from each sample and IP with CBP followed by IB for Kv2.1. Input represents one-tenth of total cytoplasmic extract used in the Co-IP assay. (b) Effects of CBP siRNA on nuclear expression of CBP. INS-1 $\beta$-cells transfected with CBP siRNA or Control scrambled siRNA (100 nM), and incubated for $72 \mathrm{~h}$. Western blot analyses were performed as described in Materials and Methods, using antibody against CBP, histone and $\beta$-actin. (c) Effects of CBP siRNA on GIP/GLP-1 mediated acetylation of Kv2.1. $\beta$-INS-1 cells were transfected with Kv2.1 and CBP siRNA, and incubated with GIP or GLP-1 (100 nM) for $1 \mathrm{~h}$. Cytoplasmic extracts were isolated from each sample and IP with Kv2.1 followed by IB for acetyl-Lys. Input represents one-tenth of total protein extract used in the Co-IP assay. (d) Effects of CBP siRNA on GIP/GLP-1 mediated protein-protein interaction between Kv2.1 and CBP. INS-1 $\beta$-cells were transfected with Kv2.1 and siRNA as described above, and incubated with GIP or GLP-1 (100 nM) for $1 \mathrm{~h}$. Cytoplasmic extracts were isolated from each sample and IP with CBP followed by IB for Kv2.1. Input represents one-tenth of total cytoplasmic extract used in the Co-IP assay. (e) Effects of GIP and GLP-1 on Kv2.1 surface expression. Human islet cells were treated with $100 \mathrm{nM}$ of indicated peptides, GIP (1-42), GIP analog (19-30), GLP-1 (7-36) and GLP-1 analog (9-36) for $1 \mathrm{~h}$. Proteinase $\mathrm{K}$ was applied for $30 \mathrm{~min}$, and cell lysates were analyzed for Kv 2.1 by SDS-PAGE and IB as described in Proteinase $K$ digestion experiments of Materials and methods. The arrow labeled $S$ indicates the immunoblot position of surface Kv2.1, and the arrow labeled / indicates the intracellular Kv2.1. (f) Densitometric analysis of (e). Western blots were quantified and normalized with the loading control, $\beta$-tubulin. Shown are fold differences versus - Control. Western blots are representative of $n=3$ and significance was tested using ANOVA with Newman-Keuls post hoc test, where ${ }^{* *}$ represents $P<0.05$ versus-Control

colorimetric assay following release of dye from the apoptotic cells (representative images for APOPercentage dye labelled cells can be found in Supplementary Figure 4).

Cell fractionations. Nuclear/cytoplasmic extracts were prepared from cells as described previously. ${ }^{4,5,18}$ Briefly, cells were washed with PBS, and scraped with $200 \mu$ ice-cold buffer A (10 mM HEPES pH 7.9, $10 \mathrm{mM} \mathrm{KCl}, 1.5 \mathrm{mM} \mathrm{MgCl}_{2}, 1 \mathrm{mM}$ EDTA, $1 \mathrm{mM}$ dithiothreitol, $0.1 \%$ Nonidet P40 and protease inhibitors). Following centrifugation, supernatants (cytoplasmic extracts) were collected and resulting pellets re-suspended in $20 \mu \mathrm{l}$ buffer $\mathrm{B}$ ( $20 \mathrm{mM}$ HEPES, pH 7.9, $400 \mathrm{mM} \mathrm{NaCl}, 1 \mathrm{mM}$ EDTA, $1 \mathrm{mM}$ dithiothreitol, $20 \%$ glycerol and protease inhibitors) and incubated on ice for $10 \mathrm{~min}$. After clarification by centrifugation, supernatants (nuclear extracts) were collected and subjected to western blot analysis. Histone and $\beta$-actin were used as nuclear and non-nuclear markers, respectively, to establish lack of crosscontamination between fractions (Supplementary Figure 5).

Western blot analysis. Protein samples were separated on a $15 \%$ sodium dodecyl sulfate (SDS)/polyacrylamide gel and transferred onto nitrocellulose membranes (Bio-Rad Laboratories, Mississauga, ON, Canada). Probing of the membranes was performed with Kv2.1, phospho-Ser/Thr, acetyl-Lys, CBP, p300, histone or $\beta$-actin antibodies (Cell Signaling Technology, Beverly, MA, USA; Santa Cruz Biotechnology, Santa Cruz, CA, USA; Sigma-Aldrich; Novus Biologicals, Littleton, CO, USA). Immunoreactive bands were visualized by enhanced chemiluminescence (Millipore, Billerica, MA, USA) using horseradish peroxidase-conjugated IgG secondary antibodies.

Co-immunoprecipitation (Co-IP). For the data presented in Figure 2, total cellular extracts were prepared following experimental treatments and immunoprecipitated with phospho-serine/threonine, acetyl-lysine or Kv2.1 antibodies using Dynabead protein A (Invitrogen). Precipitated products were resolved by SDS-PAGE and probed with antibodies against Kv2.1, phospho-serine/ threonine or acetyl-lysine.

Confocal microscopy. $\beta$-INS-1 cells were treated with GIP or GLP-1 $(100 \mathrm{nM})$ for $1 \mathrm{~h}$. Immunocytochemical staining was performed using antibodies against CBP, and visualized with Texas Red dye-conjugated anti-rabbit secondary antibody (Molecular Probes, Invitrogen Canada, Burlington, ON, Canada). Cell nuclei were counterstained with DAPI (4',6-diamino-2-phenylindole). Stained cells were imaged using a Nikon confocal microscope (Nikon Canada, Mississauga, ON, Canada). All imaging data were analyzed using EZC1 software (Nikon).

RNA interference knockdown of CBP and Kv2.1. $\beta$-INS-1 cells were transfected with MISSION siRNA for CBP (SASI_Rn01_00079791, Sigma-Aldrich) or Kv2.1 (SI01527631, Qiagen Canada, Toronto, ON, Canada) and incubated for $72 \mathrm{~h}$. The level of reduction in CBP and Kv2.1 protein expression was determined by western blot hybridization using antibodies against CBP, Kv2.1, histone and $\beta$-actin.

Proteinase K digestion experiments. For proteinase $\mathrm{K}$ digestion, ${ }^{11}$ human islets incubated with $100 \mathrm{nM}$ of each peptide were washed three times with ice-cold PBS and incubated with $10 \mathrm{mM} \mathrm{HEPES}, 150 \mathrm{mM} \mathrm{NaCl}$ and $2 \mathrm{mM} \mathrm{CaCl}_{2}$ (pH 7.4) with $200 \mu \mathrm{g} / \mathrm{ml}$ proteinase $\mathrm{K}$ at $37^{\circ} \mathrm{C}$ for $30 \mathrm{~min}$. Cells were harvested and proteinase $\mathrm{K}$ digestion quenched with ice-cold PBS containing $6 \mathrm{mM}$ phenylmethylsulfonyl fluoride and $25 \mathrm{mM}$ EDTA. This was followed by
SDS-PAGE and immunoblotting, and probing of membranes with antibodies against Kv channels and $\beta$-tubulin.

Statistical analysis. Data are expressed as means \pm S.E.M. with numbers of individual experiments presented in figure legends. Significance was tested using analysis of variance (ANOVA) with Newman-Keuls post hoc test $(P<0.05)$.

\section{Conflict of Interest}

The authors declare no conflict of interest.

Acknowledgements. These studies were generously supported by funding from the Canadian Institutes of Health Research (ClHR), Canadian Diabetes Association and the Michael Smith Foundation for Health Research (MSFHR) (to CHSMc), from the Canadian Foundation for Innovation, MSFHR, PA Woodward Foundation and the lke Barber Diabetes Research Endowment (to GW) and from MSFHR (Graduate fellowship) (to SW). We would like to thank Dr. C B Newgard (Duke University Medical Center, Durham, NC, USA) for INS-1 cells (clone 832/13).

1. Drucker DJ. The role of gut hormones in glucose homeostasis. J Clin Invest 2007; 117: 24-32.

2. McIntosh CHS, Widenmaier S, Kim SJ. Pleiotropic actions of the incretin hormones. Vitam Horm 2010; 84: 21-79.

3. McIntosh CHS, Widenmaier S, Kim SJ. Glucose-dependent insulinotropic polypeptide (gastric inhibitory polypeptide; GIP). Vitam Horm 2009; 80: 409-471.

4. Kim SJ, Winter K, Nian C, Tsuneoka M, Koda Y, Mclntosh CHS. Glucose-dependent insulinotropic polypeptide (GIP) stimulation of pancreatic beta-cell survival is dependent upon phosphatidylinositol 3-kinase (PI3 K)/protein kinase $\mathrm{B}$ (PKB) signaling, inactivation of the forkhead transcription factor Foxo1, and down-regulation of bax expression. $J$ Biol Chem 2005; 280: 22297-22307.

5. Kim SJ, Nian C, Widenmaier S, McIntosh CHS. Glucose-dependent insulinotropic polypeptide (GIP) mediated up-regulation of $\beta$-cell anti-apoptotic $B c l-2$ gene expression is coordinated by cAMP-response element binding protein (CREB) and CAMP-responsive CREB coactivator 2 (TORC2). Mol Cell Biol 2008; 28: 1644-1656.

6. Widenmaier SB, Ao Z, Kim SJ, Warnock G, McIntosh CHS. Suppression of p38 MAPK and JNK via Akt-mediated inhibition of apoptosis signal regulating kinase 1 constitutes a core component of the beta-cell pro-survival effects of glucose-dependent insulinotropic polypeptide. J Biol Chem 2009; 284: 30372-30382

7. Jitrapakdee S, Wutthisathapornchai A, Wallace JC, MacDonald MJ. Regulation of insulin secretion: role of mitochondrial signaling. Diabetologia 2010; 53: 1019-1032.

8. Aras MA, Aizenman E. Obligatory role of ASK1 in the apoptotic surge of $\mathrm{K}+$ currents. Neurosci Lett 2005; 387: 136-140.

9. McLaughlin B, Pal S, Tran MP, Parsons AA, Barone FC, Erhardt JA et al. p38 activation is required upstream of potassium current enhancement and caspase cleavage in thiol oxidant-induced neuronal apoptosis. J Neurosci 2001; 21: 3303-3311.

10. MacDonald PE, Wheeler MB. Voltage-dependent $\mathrm{K}^{+}$channels in pancreatic beta cells: role, regulation and potential as therapeutic targets. Diabetologia 2003; 46: 1046-1062.

11. Kim SJ, Choi WS, Han JS, Warnock G, Fedida D, Mclntosh CHS. A novel mechanism for the suppression of a voltage-gated potassium channel by glucose-dependent insulinotropic polypeptide: protein kinase A-dependent endocytosis. J Biol Chem 2005; 280: 28692 28700

12. MacDonald PE, Ha XF, Wang J, Smukler SR, Sun AM, Gaisano HY et al. Members of the $\mathrm{Kv} 1$ and $\mathrm{Kv} 2$ voltage-dependent $\mathrm{K}^{+}$channel families regulate insulin secretion. Mol Endocrinol 2001; 15: 1423-1435.

13. Jacobson DA, Kuznetsov A, Lopez JP, Kash S, Ammälä CE, Philipson LH. Kv2.1 ablation alters glucose-induced islet electrical activity, enhancing insulin secretion. Cell Metab 2007; 6: 229-235. 
14. Burg ED, Remillard CV, Yuan JXJ. K+ channels in apoptosis. J Memb Biol 2006; 209: 3-20.

15. Storey NM, Gómez-Angelats M, Bortner CD, Armstrong DL, Cidlowski JA. Stimulation of Kv1.3 potassium channels by death receptors during apoptosis in Jurkat T-lymphocytes. J Biol Chem 2003; 278: 33319-33326.

16. Pal SK, Takimoto K, Aizenman E, Levitan ES. Apoptotic surface delivery of $\mathrm{K}^{+}$channels. Cell Death Differ 2006; 13: 661-667.

17. Close P, Creppe C, Gillard M, Ladang A, Chapelle JP, Nguyen L et al. The emerging role of lysine acetylation of non-nuclear proteins. Cell Mol Life Sci 2010; 67: 1255-1264.

18. Kim SJ, Nian C, Mclntosh CHS. Glucose-dependent insulinotropic polypeptide and glucagon-like peptide-1 modulate beta-cell chromatin structure. J Biol Chem 2009; 284: 12896-12904.

19. Ma L, Gao JS, Guan Y, Shi X, Zhang H, Ayrapetov MK et al. Acetylation modulates prolactin receptor dimerization. Proc Natl Acad Sci USA 2010; 107: 19314-19319.

20. Kalkhoven E. CBP and p300: HATs for different occasions. Biochem Pharmacol 2004; 68: $1145-1155$.

21. Bortner CD, Cidlowski JA. Cell shrinkage and monovalent cation fluxes: Role in apoptosis. Arch Biochem Biophys 2007; 462: 176-188.

22. Yu SP, Choi DW. Ions, cell volume and apoptosis. Proc Natl Acad Sci USA 2000; 97 : 9360-9362.

23. MacDonald PE, Sewing S, Wang J, Joseph JW, Smukler SR, Sakellaropoulos G et al. Inhibition of Kv2.1 voltage-dependent $\mathrm{K}^{+}$channels in pancreatic beta-cells enhances glucose-dependent insulin secretion. J Biol Chem 2002; 277: 44938-44945.

24. MacDonald PE, Salapatek AM, Wheeler MB. Glucagon-like peptide-1 receptor activation antagonizes voltage-dependent repolarizing $\mathrm{K}^{+}$currents in beta-cells: a possible glucosedependent insulinotropic mechanism. Diabetes 2002; 51: S443-S447.

25. MacDonald PE, Wang X, Xia F, El-kholy W, Targonsky ED, Tsushima RG et al. Antagonism of rat beta-cell voltage-dependent $\mathrm{K}^{+}$currents by exendin 4 requires dual activation of the CAMP/protein kinase $\mathrm{A}$ and phosphatidylinositol 3-kinase signaling pathways. J Biol Chem 2003; 278: 52446-52453.

26. Benítez-Rangel E, García L, Namorado MC, Reyes JL, Guerrero-Hernández A. Ion channel inhibitors block caspase activation by mechanisms other than restoring intracellular potassium concentration. Cell Death Dis 2011; 2: e113.

27. Leung YM, Kang Y, Gao X, Xia F, Xie H, Sheu L et al. Syntaxin $1 \mathrm{~A}$ binds to the cytoplasmic $\mathrm{C}$ terminus of Kv2.1 to regulate channel gating and trafficking. J Biol Chem 2003; 278 17532-17538.
28. Xia F, Gao X, Kwan E, Lam PP, Chan L, Sy K et al. Disruption of pancreatic beta-cell lipid rafts modifies Kv2.1 channel gating and insulin exocytosis. J Biol Chem 2004; 279: 24685246891.

29. Feinshreiber L, Singer-Lahat D, Friedrich R, Matti U, Sheinin A, Yizhar $O$ et al. Nonconducting function of the Kv2.1 channel enables it to recruit vesicles for release in neuroendocrine and nerve cells. J Cell Sci 2010; 123: 1940-1947.

30. O'Connell KM, Loftus R, Tamkun MM. Localization-dependent activity of the Kv2.1 delayed-rectifier $\mathrm{K}+$ channel. Proc Natl Acad Sci USA 2010; 107: 12351-12356.

31. Park KS, Mohapatra DP, Misonou H, Trimmer JS. Graded regulation of the Kv2.1 potassium channel by variable phosphorylation. Science 2006; 313: 976-979.

32. Dai XQ, Kolic J, Marchi P, Sipione S, Macdonald PE. SUMOylation regulates Kv2.1 and modulates pancreatic beta-cell excitability. J Cell Sci 2009; 122: 775-779.

33. Redman PT, He K, Hartnett KA, Jefferson BS, Hu L, Rosenberg PA et al. Apoptotic surge of potassium currents is mediated by p38 phosphorylation of Kv2.1. Proc Natl Acad Sci USA 2007; 104: 3568-3573.

34. Sobko A, Peretz A, Attali B. Constitutive activation of delayed-rectifier potassium channels by a src family tyrosine kinase in Schwann cells. EMBO J 1998; 17: 4723-4734.

35. Redman PT, Hartnett KA, Aras MA, Levitan ES, Aizenman E. Regulation of apoptotic potassium currents by coordinated zinc-dependent signalling. J Physiol 2009; 587: 4393-4404.

36. Jiao S, Liu Z, Ren WH, Ding Y, Zhang YQ, Zhang ZH et al. cAMP/protein kinase A signaling pathway protects against neuronal apoptosis and is associated with modulation of Kv2.1 in cerebellar granule cells. J Neurochem 2007; 100: 979-991.

37. Choudhary C, Kumar C, Gnad F, Nielsen ML, Rehman M, Walther TC et al. Lysine acetylation targets protein complexes and co-regulates major cellular functions. Science 2009; 325: 834-840

38. Yang XJ, Seto E. Lysine acetylation: codified crosstalk with other posttranslational modficiations. Mol Cell 2008; 31: 449-461.

39. Larsen L, Tonnesen M, Ronn SG, Størling J, Jørgensen S, Mascagni P et al. Inhibition of histone deacetylases prevents cytokine-induced toxicity in beta cells. Diabetologia 2007; 50: 779-789

40. Lundh M, Christensen DP, Rasmussen DN, Mascagni P, Dinarello CA, Billestrup N et al. Lysine deacetylases are produced in pancreatic beta cells and are differentially regulated by proinflammatory cytokines. Diabetologia 2010; 53: 2569-2578.

\section{Supplementary Information accompanies the paper on Cell Death and Differentiation website (http://www.nature.com/cdd)}

